\title{
Academic success in schools in the Algarve: when leadership is part of the solution and not of the problem*
}

\author{
HELENA QUINTAS \\ Universidade de Algarve, Faro, Portugal
}

JOSÉ ALBERTO GONÇALVES

Universidade de Algarve, Faro, Portugal

SANDRA VALADAS

Universidade de Algarve, Faro, Portugal

\begin{abstract}
This paper presents the results of a case study conducted among school principals in the southern region of Portugal, located in urban, suburban and rural settings. The five cases that comprise this study were subjected to a final rating of "Very Good" in the external evaluation process of schools, whose data were collected through semi-structured interviews and documentary analysis (regulations and educational project, reports of the external evaluation of responsibility of Inspeção Geral de Educação e Ciência de Portugal). The data collected in this exploratory study were systematized and analyzed according to the following indicators: the students' academic success, the teachers' professional development, the organizational development and the identifying features of schools principals. Overall, we cannot affirm the existence of differences according to geographical area, although some particularities which proved to be interesting and indicative of good leadership practices could be highlighted.

\section{KEYWORDS}

school administration and management; successful leadership; pupils' academic success; decision-making; promotion and dissemination of information.
\end{abstract}

* This paper is financed by National Funds provided by FCT-Foundation for Science and Technology through project PTDC/CPE/116674/2010. 


\section{SUCESSO ACADÊMICO EM ESCOLAS NO ALGARVE: QUANDO A LIDERANÇA É UMA PARTE DA SOLUÇÃO E NÃO O PROBLEMA}

RESUMO

Neste artigo apresentam-se os resultados obtidos num estudo de caso realizado com diretores de escolas da região sul de Portugal, tendo sido considerados os meios urbano, suburbano e rural. Os cinco casos que constituem este estudo foram alvo de uma classificação final de "Muito Bom" na avaliação externa de escolas, tendo os dados sido recolhidos por meio de entrevistas semiestruturadas e da análise documental (regulamentos e projeto educativo, relatórios da avaliação externa da responsabilidade da Inspeção Geral de Educação e Ciência de Portugal). Os dados recolhidos neste estudo ainda exploratório foram sistematizados e analisados à luz dos seguintes indicadores: o sucesso escolar dos alunos, o desenvolvimento profissional docente, o desenvolvimento organizacional e as características particulares dos diretores. No geral, não podemos afirmar a existência de diferenças em função da área geográfica, sendo, contudo, possível destacar algumas particularidades que se revelaram interessantes e indicativas de boas práticas de liderança.

\section{PALAVRAS-CHAVE}

administração e gestão escolar; liderança de sucesso; sucesso escolar dos alunos; tomada de decisão; dinamização e circulação da informação.

\section{ÉXITO ACADÉMICO EN LAS ESCUELAS EN EL ALGARVE: CUANDO EL LIDERAZGO ES UNA PARTE DE LA SOLUCIÓN EN LUGAR DEL PROBLEMA}

\section{RESUMEN}

En este trabajo se presentan los resultados de un estudio de caso hecho con directores de escuelas de la región sur de Portugal. Fueran consideradas áreas urbanas, suburbanas y rurales. Los cinco casos que componen este estudio han sido calificados con la evaluación final de "Muy Bueno" en el proceso de evaluación externa de los centros educativos. Los datos fueron colectados a través de entrevistas semi-estructuradas y análisis documental (reglamentos y proyectos educativos, bien como los informes de la evaluación externa de la responsabilidad de la "Inspeção Geral de Educação e Ciência de Portugal"). Los datos recogidos en este estudio aún exploratorio fueran sistematizados y analizados de acuerdo con los siguientes indicadores: el éxito académico de los estudiantes, el desarrollo profesional docente, desarrollo organizacional y características de personalidad de los directores de los centros educativos. En general, no podemos observar diferencias en los resultados en función del área geográfica, siendo, sin embargo, posible poner en relieve algunas de las peculiaridades que resultan indicativas de buenas prácticas de liderazgo.

\section{PALABRAS CLAVE}

administración y gestión escolar; liderazgo; éxito académico de los estudiantes; toma de decisiones; racionalización y flujo de información. 


\section{INTRODUCTION}

The administration and management of Portuguese schools are governed by a single legal framework, regardless of the social, cultural and economic development differences in the various regions throughout the country and, consequently, in public schools. Although based on democratic principles, the prevailing legislation concentrates the responsibility for pupils' academic success in the school leadership, and the principal has the necessary authority to develop the educational project in the school and to carry out educational policy measures locally. School principals are responsible for managing the human resources and also for providing the public service of education. They have a dual role to play: that of a manager and that of a leader. As managers, they must control their school's budget and administer other instruments used to organize life in the school; as leaders, they must establish goals for the future, encourage commitments and orientate change. This is an exercise in multiple, dynamic leadership, which must be based on dialogue and interaction with the other teachers in the school and allow specific local issues to be addressed. It also involves making decisions that may be fundamental for the professional development of the teachers and the organization of the school, such as the diversity of courses offered.

In this paper, the results of a case study carried out in Algarve - southernmost and extremely diverse region in Portugal -, both in geographical and in cultural terms, are presented:

- the coastal area, very touristic and more economically developed, where the majority of the population lives, though affected by a variety of problems such as the seasonal nature of employment and the integration of migrant populations, considering its ethnic and cultural diversity; and

- the rural area, where the region's culture and traditional production methods are preserved, but which suffers from problems such as the aging of the population, marked depopulation and a lack of expectations for the future.

In this varied terrain, the schools and their principals have to find solutions which will lead pupils to success and, through creative and assertive leadership practices, rise to the challenges that circumstances place in their path. They do so, however, by employing a variety of means, such as strengthening the role of those holding intermediate leadership positions, sharing the decision-making processes, promoting the dissemination of information and by the creative, effective and innovative use of resources.

The data were collected by means of interviews conducted with the principals of five schools, located in various settings, thus enabling us to analyze the methods and processes used by school principals to address the challenges they face in the exercise of leadership, which is seen as a solution for the problems faced by schools and which, therefore, appear to make a significant contribution toward the pupils' academic success. 
These preliminary findings were systematized based on three socio-educational realities: urban schools, suburban schools and rural schools.

\section{FROM MANAGEMENT TO LEADERSHIP: A CHANGE OF PARADIGM}

The approach to the concept of leadership and the researches on it are relatively recent in Portugal, and both the legislation and the representative universe of teachers and schools - specifically the principals - continue to maintain a classic position of administration and management of the educational organization. According to Bolívar (2012), the school management model used in Portugal is currently going through "a transitional period between a bureaucratic-administrative school management system, typical of early modernity, and the new guidelines for pedagogical leadership" (Bolívar, 2012, p. 49, translated by the author). Indeed, this can be seen from some of the recent amendments to legislation, such as the provisions of Decree-Law 75/2008 (April 22 ${ }^{\text {nd }}$ ), which creates the figure of the principal (Bolívar, 2012), and Decree-Laws 224/2009 (September 11 ${ }^{\text {th }}$ ), and 137/2012 (July $2^{\text {nd }}$ ), which introduce amendments to the former, by reinforcing, for example, the principal's singular role with capacity to appoint his or her deputies and assistants (Regulatory Ordinance 13-A/2012, June $5^{\text {th }}$ ). These legal diplomas represent a change of paradigm, regarding two aspects: that of leadership, personified in the figure of the principal; and that of schools' autonomy, which has been established more as a result of controlling body's action than by a fundamental movement of the educational organizations. In this respect, diploma 13-A/2012 considers the need to "establish the mechanisms for each school to exercise pedagogical autonomy" and allow schools "to implement their own projects, which valorize worthwhile experiences and promote collaborative practices in keeping with the human and material resources at their disposal". These provisions appear to lean toward the idea that the leadership of school organizations should be seen as a means for the development of an educational and pedagogical undertaking (Costa, 2000), with the "principals' pedagogical leadership" being seen not only as a key factor for change and improvement in schools but also as constituting "a prime critical factor for the improvement of education" (Bolívar, 2012, p. 48, translated by the author). This should not, however, prevent leadership from being shared (Sergiovanni, 1988; 2004), requiring, on the one hand, effectiveness and, on the other, strategies and commitment by both individuals and the entire educational community (English, 2008; Fullan, 2001; Nóvoa, 1992).

It should, however, be emphasized — given the Portuguese education system's tradition -, that management and leadership are not divergent or antagonistic, but actually rather complementary factors in the exercise of heading a school. Thus, while the manager's role consists of running the institution in line with the general and specific regulations (Ruzafa, 2003) - involving a function which has more to do with control through budgeting, the planning of activities and other organizational and regulatory instruments for school life - , the leader should, above all, establish goals for the future, encouraging commitment and promoting changes (Bolman \& Deal, 1994 apud Estêvão, 2000). Therefore, while exercising 
leadership, the principal should focus on the activities actually undertaken in the school and promote constant dialogue and interaction between teachers, so that they can identify the problems faced in their practices (Ruzafa,2003). The principal must also invest in the courses available, the teachers' professional development and the organizational development of the entire school (Gairín-Sallán \& Villa Sánchez,1999). According to Bolívar (1997), all this effort is a process that defines the multi-faceted and dynamic exercise of leadership.

This exercising of leadership, which presumes a combination of skills on various levels - technical, instrumental, moral action and transformation - which are, in fact, built up through training and learning (English, 2008; Sanches, 1996), is undertaken on the basis of three types of variables (the personal characteristics of the principal, the organizational structures and the school's culture). It is also influenced by three factors:

- legal, in terms of the legal or formal statute of the position in the school organization;

- personal aspects, as a consequence of the principal's personal characteristics; and

- functional, which has to do with the characteristics of the group and the degree of suitability (Ciscar \& Uria, 1986 apud Gairín-Sallán \& Villa Sánchez, 1999).

In fact, the exercise of leadership of school organizations encompasses technical, human, pedagogical, symbolic, cultural and political dimensions (GairínSallán \& Villa Sánchez, 1999).In order for it to be successful, one cannot ignore the moral dimension of education, the social and interpersonal nature of educational practices, their instructional dimension and the political nature of education (Alves, 1999). As such, the principal, while still taking charge of administrative tasks, also functions as a driving force for "change and participation", the coordinator of the action of the various organizations (Fonseca, 2000) and, mainly, the "communicator" who takes steps to avoid conflicts and manages and mediates them when they do arise, promotes and encourages good relations between the various elements of the school community and takes decisions which are appropriate to the school's interests and needs (Fullan, 2001).

The collegial model of management and leadership, which has been the norm in the educational system in Portugal, has resulted in internal decentralization of management, which is exercised in a disperse way, leading to multiple leaderships which ought to work in an articulated and complementary manner (Ainley \& McKenzie, 2000). This leadership practice is based on rotating roles, since teachers may take on different roles within the educational organization. This fact expands their perception on reality and allows secure, shared governance relationships, by learning from and with each other, as well as creating a culture of collaboration, relationship and bonding with the community (Beattie, 2002; Gold et al., 2003; Leithwood, 1994). Hence the leadership should take advantage of the collaboration and commitment of every member of the educational community (teachers, pupils and families), in order to provide structures and propitious means to dialogue, thus 
encouraging them to participate in the governance and in management of the curriculum. Subsequently, conditions would be created, not only for the multiple voices expressing different ideas in the processes of change and organizational development (Robertson, 1998; Ross \& Gray, 2006), but would also allow for the leadership to make decisions which would enhance pupils' educational success - after the teachers'work, "leadership is the second most contributory factor to pupils learning," (Bolívar, 2012, p. 91, translated by the author) -, the professional development of teachers and the organizational development of the school.

In short, the action of leadership must be creative and innovative insofar as leading is a creative process in which leaders must create and recreate learning communities (Barker, 2007). In this sense, the principals are agents of change and resources that take advantage of the skills of the other participants, in benefit of a common vision and mission (Bolívar, 2012, p. 67).

In this process, one must not forget that educational organizations are complex systems for which the functioning and dissemination of information is fundamental and encourages change. Additionally, the intensity and quality of the information depend on the level of production of knowledge and the degree of interaction between the structures, as well as on the culture of communication which exists within the system (Fullan, 2001). In Portugal, the coexistence, in the same school, of teaching staff with different training and who teach distinct stages/levels of education, along with the geographical dispersion, may constitute barriers which could difficult dialogue and limit the dissemination of information. Whatever the type of school, the effective use of information can be seen as a successful way of identifying expectations and stimulating processes of questioning and discussion, later translated into development (Creemers \& Reezigt, 2005; Coppieters, 2005). The maintenance of circuits which allow the dissemination of information ensuring that the knowledge about the school can be established is, therefore, a condition that principals should observe and guarantee. Principals must ensure the dissemination and quality of the information, as well as the variety and diversity of means and ways in which it circulates. They must also ensure the efficacy, by means of a system of delegation of responsibilities, which guarantees that the existing knowledge about the indicators of school's development, progress and improvement is appropriate to the educational community.

If the principles and conditions we have been discussing are put into practice, they will enable the promotion of "professional communities, with shared goals and values" (Bolívar, 2012, p. 60, translated by the author), the possibility of implementing "school-based management with decisions being taken at school level", emancipating leadership from its usual formal role, and "breaking away from the uniformity of structures, making it possible for each school to have its own structures" (Bolívar, 2012, p. 61, translated by the author).

\section{METHODOLOGICAL ASPECTS}

The analysis of differences and similarities in successful leaderships of schools in three distinct geographical settings (rural, suburban and urban) was the main 
goal of this study. Four aspects were focused: the pupils' educational success, the teachers' professional development, the schools' organizational development, and the identifying features of the principals (Bolívar, 2012; Fonseca, 2000; GairínSallán and Villa Sánchez, 1999).

Five principals participated in this study, from schools where the leadership had been classified as "Very Good" in the external evaluation process undertaken by the Portuguese Inspeção Geral de Educação e Ciência (responsible for the schools' assessment - both public and private - based on different indicators related to products - academic, social, community - teaching and learning processes, and leadership and management). Two of the schools are located in an urban setting; two others are located in a suburban setting, in small localities along the coast of Algarve; and, lastly, one of the schools is located in a rural setting in an upland area of the Algarve's interior. Of the five interviewees, three are women and two are men, reflecting the reality of the upper echelons of leadership in the Portuguese educational system.

Given the nature of the study, we used a qualitative approach "of particular importance to the study of social relationships, given the plurality of contexts in which we live" (Flick, 2005, p. 4, translated by the author), which relates back to the understanding of phenomena and/or reality, without fragmenting or decontextualizing it (Almeida \& Freire, 2008), ensuring, therefore, that the study encompasses a variety of subjects and situations; in this case, and according to Guerra (2006), giving emphasis to internal diversity, as the intention was to explore diversity in a relatively homogenous set of subjects. In terms of methodological strategy, because we intended to "conduct an in-depth inquiry to examine the life cycle or some particular aspect" (Carvalho, 2002, p. 126, translated by the author), a case study was performed (Bogdan \& Biklen, 1997).

In terms of methodological strategy, we held a case study focused on researching an individual unit, which may be a group, and that usually translates into analysis a current phenomenon in its own context (Cohen \& Manion, 1990). According to Carvalho (2002, p. 126, translated by the author), this is a design commonly used when the researcher aims to "conduct an inquiry in depth to examine the life cycle or some particular aspect". In the current investigation, the cases consist of school principals who represent the top leadership of school organizations in the current Portuguese educational system. Although there are other leadership levels of both administrative and pedagogical important responsibilities, the main interest of this study was school principals. According to recent legislation, they saw their powers and responsibilities reinforced both in regard of the quality of service provided by the schools and the students' academic success.

Considering we were investigating several participants and tried to analyze the way they manage and lead schools (as well as the importance principals attach to the aforementioned aspects), we decided for a case study in its multi-case variant. According to Fortin (2000, p. 65, translated by the author) "multi cases comparison is the methodology that best allows to find convergences between several cases".

We conducted semi-structured interviews with the selected school principals. The script included questions related to each principal's biographical details and to 
the leadership strategy, taking into account how these factors affected the success achieved, the pupils, the teachers and the school organization.

In order to process the information gathered during the interviews, we followed the indications of the simplified process for content analysis advocated by Guerra (2006), based on the proposals made by Poirier and Valladon (1983 apud Guerra, 2006, p. 69, translated by the author), whereby "content analysis seeks to describe the situations but also to interpret the meaning of what was said". In order to conclude the process, we drew up a synoptic grid which enabled us to conduct a comprehensive and inductive analysis of the data (Quivy \& Campenhoudt, 1995), triangulating them with the results of the documentary analysis carried out on the schools' internal documents and the External Evaluation Reports (made by Inspeção Geral de Educação e Ciência), allowing us to interpret them in a more meticulous and sustained manner.

\section{RESULTS}

Results are presented based on the pupils' educational success, the teachers' professional development, the schools' organizational development and the identifying features of the various principals (Bolívar, 2012; Fonseca, 2000; Gairín-Sallán and Villa Sánchez, 1999). As mentioned before, we considered the decision-making processes of the leaderships of the schools located in different settings.

\section{URBAN SETTINGS: LEADERSHIPS GEARED TOWARDS SUCCESS AND SOCIO-EDUCATIONAL AFFIRMATION}

When analyzing the "pupils' educational success", both interviewees mentioned strategies to improve academic results and highlighted the need for the schools to continue preparing and training pupils successfully, creating a feeling of belonging and a liking. Apart from these aspects, one of the principals pointed out the need to promote "a demanding school, a rigorous school", where "the pupils become, in particular, good citizens, whether as engineers, chefs, or whatever else they do in life". The interviewee added that it is important "that they [the pupils] have enjoyed their time here". Similarly, both acknowledge that the "truth atmosphere" of the school, the sharing of knowledge and a "good relationship with the youngsters" also constitutes factors propitious to their success. As one of the principals put it: "what I am aiming at is that the pupils' success is achieved in such a way that everyone in the school feels fulfilled (...) which necessarily implies the well-being and success of the teachers too".

From this discourse, we were able to understand the importance given to some vectors for success. The principals interviewed expressed their concern with the development of a successful learning community through the conducting of activities and the undertaking of projects that can be recognized by everyone involved due to their upkeep of a positive ambience, which encourages an environment that favors learning and appeals to staff, pupils and parents alike. As far as projects and 
activities are concerned, these are seen as a means of showing the community what is being achieved and what is important for success to be obtained.

When asked about the problem of discipline, both principals affirmed that, apart from being rare, such problems were quickly analyzed and easily resolved. One of the interviewees explained that this was the case because "there's time to talk [and] to (...) understand why the particular pupil in question behaved in such a way".

It is suggested that the familiar ambience is a determining factor in understanding disruptive behavior by pupils. In this respect, we would highlight the strategy of one of the interviewees when faced with a situation of this nature: "when they come in [to the principal's office] they are always good pupils and I treat them as such".

The other principal considers that the promotion of a "culture of discipline, effort and responsibility by all" is a determining factor.

Special significance is also given to partnerships and support, which make a determining contribution to the diversification of pedagogical activities at both schools.

"more activities and anything that can be classed as an activity and which leads to the pupils going home and saying they did this or that" is positive for the teaching school's image, "since it broadcasts the internal strategies of organization and action".

The interviewees considered that the pupils' success had also been encouraged by the quality of the teaching staff, by their professionalism and also by the existence of "study support" provided by the "teachers themselves". Thus, the pupils' academic achievements were seen as a consequence of the teaching staff's efforts. Apart from these aspects, the importance given by the teaching staff to pupil motivation is determining for their performance: "We instil in our pupils the notion that school is important $[\ldots]$ so that they can understand that school is very important" and has a substantiated goal, adding that essentially what was intended was that "our pupils" would feel that "learning is not a punishment", valorizing "the school and what they learn". Particular importance is given to the acquisition of social skills that enhance the school's socializing effect.

Academic success also appears to be positively influenced when teachers and pupils share decision-making, when there is good communication, when pupils are participative, and when there is effective pedagogical leadership and involvement on the part of the parents.

It is also important to note some of the barriers mentioned by the interviewees, which sometimes hamper academic success and are related to a lack of support on the part of some of the parents and the syllabuses normally used. As one of the principals said, "the syllabuses are extensive" and "the (...) approaches taken by the text books" are inappropriate. The same principal additionally stresses that "some pupils have problems with teaching and learning" and that "the lack of support by the parents" is the crux of the problem because "we [the school] cannot do everything." She cites as an example the fact that, at staff meetings, they analyze "why is the pupil not achieving?" and they discover that it is because "they don't 
bring their books [...] or they don't do their homework, for example". It is in this sense that parents play a central role in the school life, and their involvement is not limited to simply gathering information about the pupils' attitudes and marks. Rather, it is desirable that they should make suggestions as to how the conditions for teaching and learning could be improved.

With regard to the "professional development of the teaching staff", the principals valorize three mutually complementary aspects: motivation, a climate of dialogue and encouragement. Both principals stated that they consider the control they claim to have over the teaching staff as being somewhat important for the promotion of the quality of teaching:

"controlling their [the teachers] work, mainly when I have new staff, young staff; checking the curricular plans and working methods and holding parents' meetings too $[\ldots]$ and using those meetings to try and understand how satisfied the parents are".

Also highlighted is the commitment of the teaching staff toward the mission, vision and values of the school, so that a climate of dialogue is fostered and the teachers' performance acknowledged. Their effort is valorized though the supervision of activities, by getting a bearing on what parents think, and, essentially, by assessing the productivity and competence of the teaching staff. At one of the schools, all the potentially interested agents (teaching and non-teaching staff, and parents) cooperated in drawing up the school's educational project.

As far as the "organizational development of the school" is concerned, both principals involve the teachers and the community in the decision-making process, by maintaining a constant dialogue and by valorizing the schools' self-assessment. Both highlight the need for a "clear definition of goals" from a perspective of shared management. Normally, conflicts are resolved immediately at both schools.

“(...) some decisions have to be taken by the principal, but the pedagogical decisions - and this is the part I most enjoy working on -, the pedagogical decisions are always taken in line with what everyone involved in the pedagogical side thinks and so decisions are always made in conjunction with everyone else. Of course, when it comes down to it, if we can't all agree, the final decision will always be mine, but even so it will be the result of a joint effort with the intermediate structures".

Both interviewees talked about "solutions involving compromise". The application of methods, practices and projects centered on innovation and improving teaching should be noted, as should the concepts of updating, competitiveness, innovation and the need to adapt to the market. The principals empower the "promotion of pupils', teachers' and non-teaching staff members' feelings of belonging”, valorizing the contribution of all and the benefits of "feeling at home". The atmosphere is, therefore, "intimate" and "relaxing". 
Services and strategies also have particular importance, especially in one of the schools, with the "promotion of the quality of administrative services and support" and the "participation in initiatives by other organizations" standing out.

Lastly, and in respect of the "identifying features of the principals", the information gathered during the interviews showed them to be fundamental players in the functioning of their schools, which would appear to be a consequence of their institutional authority and the huge diversity of tasks and issues that they handle.

Another aspect mentioned by the principals as contributing to their schools' success relates to the kind of leadership model used, where the leader who respects "others in order to be respected" is valued, and seen as a central figure in the good relationship with the teaching staff, "often [being seen] more as a colleague and a driving force for an environment that is more conducive to learning". "Public relations" and constant "diplomacy" skills when dealing with parents were also mentioned as being part of the equation. In this light, if there is to be success, the work "cannot be left undone"; everyone's effort counts and everyone contributes to both the administrative and pedagogical decision-making processes.

\section{SUBURBAN SETTINGS: LEADERSHIP AND PROMOTION OF SUCCESS AND PARTICIPATION}

With regard to the pupils' "educational success", both leaderships demonstrated a focus on improving academic results even when these were better than the national average, especially by trying to find "answers to the pupils' problems, needs and expectations". To achieve this goal, both principals focused primarily on: "meticulous monitoring of every factor that could have a bearing on their pupils' success"; "encouraging the involvement of parents and family using a variety of strategies", specifically "by organizing activities" with them and with the community in general; "diversifying the range of courses offered"; "establishing partnerships with various organizations (local councils, health authorities, associations etc.)"; and "participation in projects", whether instigated by schools or by local or national institutions. All these factors represent the pursuit of relationships and systematic coherence of action defended by Glatter (2007), as one of the distinctive marks of leadership. Other approaches are also worth considering "to guarantee equal opportunities for every pupil", both the "underprivileged and those of other nationalities", focusing on "pedagogical action and its diversification" and undertaking "activities outside the school". Perhaps, as a result of these decisions, there were "no occurrences of early school leavers" at either of the two schools; in one of them, "the number of cases of indiscipline and acts of violence is low".

As far as the "professional development of the teachers" is concerned, the action of the two principals was characterized, above all, by three aspects of a relational nature: motivation, a climate of dialogue, and encouragement, probably contributing to the improvement in their practices (Ruzafa, 2003). Thus, both principals seek to "encourage the teachers' commitment and participation" by demonstrating "consideration and regard for all" and attempting to give them "support in the difficulties 
and problems they encounter and/or experience". To achieve this, they promote the "creation of an atmosphere of openness and harmonious relationships between all the members of the school community", based mainly on the "creation of a climate of dialogue" and by "continuously resorting to formal and informal methods of meeting and working", thereby opening the way to the possibility of building learning communities (English, 2008; Fullan, 2001; Nóvoa, 1992). The leadership strategies included the following: "providing the teaching staff with constant encouragement", promoting a "good working atmosphere and a sense of cooperation", undoubtedly contribute by the "support for projects presented by teachers", and creating conditions that enable their "skills and attributes to be put to good use". Lastly, "continuous teacher training would also be encouraged".

With regard to the "schools" organizational development", the decision-making processes used by both principals are, according to the data, more of a practical and personal response to the way in which they exercise their leadership, than one based on an organic view of the schools they head. Common to both principals' actions in this respect are two main themes: involvement of the teachers and the community in the decision-making processes, and a certain focus on the schools' assessment. As for the first, it can be seen that both principals seek to establish "constant dialogue both within and outside their school" and a "focus on the dissemination and efficacy of information". Contributing to the achievement of these goals, internally, would be the "clear definition of strategic lines of action" and the "decentralization of functions", thereby leading to a shared management process (Ainley \& McKenzie, 2000) and, externally, "listening to community when drawing up documents related to the organization of school life", thereby promoting their commitment and participation (English, 2008; Fullan, 2001; Nóvoa, 1992). Such goals, insofar as the climate of dialogue within the school is concerned, will be achieved by "giving responsibility to the different professional groups, hierarchical levels and agents", a factor which, at one of the schools, will mean not only "clearly defining goals" and making an effort to "involve everyone in achieving them" but also "attempting to resolve conflicts as soon as they arise", "attitudes of justice and impartiality" on the part of the leadership, promoting "a sense of belonging among the teachers, pupils and staff", promoting participation, and "demonstrating conviction in attitudes and action on the part of the principal". Furthermore, the interviewee seeks to define "educational policies based on innovation and change", thus constituting the stimulus for the school process of innovation and change (Fonseca, 2000), or as the agent of change and resources (Bolívar, 2012). In the second school, the principal resorts to the "upkeep of a 'collective' leadership spirit and shared leadership" while simultaneously striving to promote the "quality of the administrative and support services" and "staff training". In what concerns the dialogue with the community, the data revealed that the principal at one of the schools promotes "participation in initiatives by other professional groups" and also "makes known the internal organization and action strategies", while the other principal "focuses on guaranteeing the quality of the services".

The second of the aforementioned themes identified, although less obvious in both interviews, relates to the assessment of the schools, and is common to both 
principals' discourses. Describing themselves as focusing on the "promotion of the self-assessment process" of their respective schools, they give particular emphasis to external evaluation in respect of "putting the report's suggestions for improvement into practice" in each case. The final purpose was to "improve conditions for providing pupils with a response that increasingly addresses their needs".

When analyzing the "features of the principals", both have, as we have already mentioned, considerable experience in school leadership, providing them with "in-depth knowledge of their educational reality". Similarly, both seek to base their leadership practice on a democratic and participative foundation despite the fact that they have sole responsibility for heading their schools. In turn, one of the principals consider that "I involve people in decision-making", even though doing so sometimes requires considerable "negotiating" skills and delegating certain functions to people whose characteristics seem to her to be the most suitable for the task, even though such decisions may not always be fully understood. Another determining factor in this field, she explains, is being able "to listen to the opinions of others", which are sometimes "very valid", and to take them into account when making her decisions, if appropriate. It should also be noted that, according to one of the principals, the ability to take steps to avoid conflict and "resolve them" when they do arise, is an extremely important personal skill for anyone heading a school.

In short, we can say that, in accordance with the statements of the two principals interviewed, personality traits such as affection and the capacity to relate to others, both internally and in relationships with the community - which facilitate the "motivation" and "mobilization" of the various educational agents and partners, and in particular the "intermediate leadership" - , contribute to the identifying features observed.

Lastly, both principals considered that the exercise of leadership requires a view of the school that is both "comprehensive" and "expansive" in time, translated in a clear and consensual definition of "goals" in pursuit that "everyone should feel involved".

\section{RURAL SETTINGS: LEADERSHIP PRACTICES AND CHALLENGES IN INLAND AREAS}

As mentioned under methodological aspects, our analysis of the decision-making processes which characterize leadership in schools in rural and inland settings is based on an interview conducted with the principal of a school that encompasses a large rural area.

Analyzing how the leadership is reflected in the "pupils' academic and educational success", the fact that the school headed by the interviewee is the only one in the geographical area analyzed that provides a public educational service, constitutes a challenge that the principal draws attention to, and which consists in "attempting to provide equal opportunities for every pupil". This purpose requires considerable flexibility in terms of educational intervention and refers to decisions of a structural nature such as the "diversification of the courses and training offered", which must be adjusted to meet the expectations of the community, and 
also micro-measures involving direct, personalized action such as "pedagogical and educational responses that focus on the individual characteristics of each pupil".

Although the academic results obtained by pupils attending this school are clearly below the national average, this situation is understandable when considering that this school "encompasses all the pupils living in the area", and also because of the "lower expectations of the parents as to the impact that schooling can have on improving living conditions". With a view to counteracting this idea, the principal mentions a number of initiatives aimed at "obtaining the parents' commitment to the academic and educational success of the pupils". Additionally, in the light of the fact that this is a widely dispersed population facing considerable difficulties in terms of getting around, transportation is provided for parents so that they can attend events and/or meetings held at the school. Furthermore, such occasions are scheduled for times that are compatible with the parents' availability. Ultimately, the "promotion of success" is the primary goal for this principal who, additionally, reaffirms his conviction that the school has a "socializing and equalizing effect" on the pupils and should "contribute to expanding their personal and cultural horizons". In order for this to happen, motivation to achieve academic success is constantly reinforced and, with this goal in mind, a common practice is to inform the community of successes achieved by former pupils.

Also regarding success, the principal places the responsibility for academic results in the hands of the teaching staff. In this respect, the principal asserts that he customarily tells his teachers that "not much is lacking at this school but the academic results are not forthcoming [and] since our pupils are not so different from the rest, the problem must lie with you and not the youngsters". The interviewee does not, therefore, attribute an external cause to the results achieved by the pupils, believing that it is the school's job to take responsibility for the academic success achieved, or not, by their pupils. This attitude is encompassed in a perspective whereby the role of the school principal is that of someone who is capable of setting goals for the future, encouraging commitment and promoting and orientating change (Bolívar, 2012; Estêvão, 2000). Although this principal considers that the quality of the results depends largely on the excellence of the work, he nevertheless defends and instigates a close, complementary relationship between the school and other institutions within the community, adopting a philosophy of working jointly with others and as part of a concept of global education. In this respect "partnerships with various organizations: local council, health authorities, associations and others" are mentioned. In his opinion, he identified a number of obstacles and constraints related to academic success:

"they don't make a direct connection between the goal they say they want to achieve and the work they need to do to attain it (...); they don't think any effort is required". In light of this situation, the leadership seeks to counteract the "lack of recognition of the value of work".

In what concerns the leadership practices aimed at the teachers' professional development, the teaching staff at schools located in settings such as the one currently 
under analysis is characterized by a polarization in relation to professional stability. Normally, in the Portuguese educational system, there is a group of teachers on permanent contracts who have been working at the same school for many years, while the time spent at the school by the rest of the teaching staff fluctuates considerably. According to what the principal says, this situation is simultaneously seen as both beneficial and prejudicial. He considers, in this context, that professional stability can mean stagnation, conformism and resistance to change, so the coming of new teachers to the school, even for short periods of time, is seen as refreshing insofar as "it's new blood, that brings with it new experiences and practices; when combined with the somewhat sluggish blood flowing in some of our veins, it makes the mixture more fluid".

As far as the professional competences of the teachers are concerned, initial training is seen as very limited, since, in the principal's opinion, "they don't teach you to be a teacher at university, they just teach you how to give a class". With regard to continuous training, the school's geographical isolation makes it difficult for teachers to attend courses offered externally. Defending the "promotion of practices of reflection among teaching staff so that they can identify 'how' and 'where' they can improve", the principal's opinion is that training should be of a practical nature, helping "to make lessons more stimulating".

Excellence in exercising the teaching profession is constantly mentioned as a key factor for pupils' success and for the professional fulfilment of teachers. In this respect, the interviewee advocates the "need to valorize the 'nobility' of the teachers' work" and throughout his entire discourse defends the school's autonomy as a management model that can enhance the quality of the service it should provide. He demands autonomy because it allows him, as a principal, "to select teachers who have the appropriate profile and skills", "to manage resources in accordance with the needs of the school community" and, further, "to choose and define the training processes" suitable to the vision and mission of the school he heads. Contrary to what appears to happen in other situations where the schools' autonomy arises through imposition by the governance, this principal sees this type of school administration and management as a useful and appropriate tool, and one which completes the leaders' actions.

As regards to "organizational development", the data gathered reveal a leadership method that is seen as "having a face and a name" (Beattie, 2002; Gold et al., 2003; Leithwood, 1994). In other words, a vision of sole leadership, in spite of the importance of there being a management team working together, both at top and intermediate leadership level, is not disregarded (Ainley \& McKenzie, 2000; Sergiovanni, 1998; 2004). When he affirms that "there have to be [in the management team] people who bring "balance' to the leadership", the interviewee defends that there should be complementarity and subsidiarity between the various leadership levels in the school.

He admits that he undertakes management tasks, when he says that it is up to him to ensure "the existence of resources, both material and human, for the schools' normal functioning", but above all, to optimize the existing resources that, in this particular case, are very scarce. The "difficulty in managing the scarcity and 
the capacity to transform barriers into resources" is the primary concern of this principal, which he expresses on various occasions throughout his discourse: "our day-to-day work is to turn clay birds into 'things' that can fly".

But a school principal's function is not limited to management; a principal must also exercise leadership. Insofar as this aspect of his job is concerned, our interviewee admits to seeking "clarity in the management team's mission and goals", and that he "monitors the school's various action plans", including those relating to the pedagogical dimension" (Bolivar, 2012; Costa, 2000). His presence and performance are also felt in his "constant monitoring of the rules and conduct of everyone who works on the school premises". In his opinion "slack discipline is a head start towards meeting your downfall (...) when there are more serious problems, I am the one who goes to the classroom rather than the pupils coming to the head's office".

The organizational development of this school is indelibly marked by the principal's performance. Conscious that the school, as an "institution", is an "example of local authority", and the running of the educational organization needs to be adapted to suit the demographic and development characteristics of the surrounding community, he seeks to "impart visibility to the work being done" as a way of valorizing the action and function of the school, seen as an institution capable of enhancing community development.

Also with the explicit goal of promoting organizational development, the principal systematically activates processes to gather opinions on the school's performance in a number of areas and puts improvement plans into action in an attempt to address the problems identified. The external evaluation reports are also an important source of information for the definition of the improvements implemented.

In what concerns the "identifying features of this principal", managing a school in a region severely affected by depopulation and economic depression is not an easy task. In-depth knowledge of the locale, a very deeply-rooted desire for the school to be able to mark the difference between the pupils' academic and educational success or failure, and also the belief that a school principal can contribute to the school's success as an institution are parts of the head's function, particularly in the case of the head of a rural school. The way in which he interprets and carries out his duties is certainly connected to the fact that he was born and has lived so far in the region where the school is located, having attended that same school as a pupil, and having been the principal there for 20 years.

The dominant identifying feature in this principal is that he is a person who takes it upon himself to manage and create conditions so that the school, as an institution, can fulfil its function, i.e., going far beyond what would normally be expected. As our interviewee sees it, the school organization is "the link in a chain to which various organizations belong and who, together, contribute (or not) to the construction of a local identity and the fulfilment of a community". This principal undertakes the political dimension of the school and, as a leader, acts based on what he thinks is expected of him. It is also by taking on a role as a local leader (Alves, 1999) — rather than that of a school principal - that this 
principal contests current educational policy that enclose schools in peripheral and disadvantaged areas, defending that the "school is a focus which attracts people to a community and develops it".

He also takes personal responsibility for promoting good relations between all those involved in the school and educational community, by making commitments with parents and the rest of the community, with a view to the pupils'success. In this respect, he acknowledges that his leadership style and practices influence the pupils' academic results (Bolívar, 2012).

However, and although he exercises a leadership which is firmly supported by his undeniably and acknowledged strong personality, he defends the worth of sharing decision-making processes, clarifying that harmony between the purposes and the goals is determinant for success.

\section{CONCLUSIONS}

This research was centered in school principals as main actors. Being aware that the mission and values of the school are not exhausted or reduced to what the principals think and do, we tried to understand aspects in which the quality of their leadership has implications on the results of the schools and the success in learning. We start, therefore, with the assertion that the principals, through their leadership, can be configured as enhancer elements of success. Assuming this can be considered a segmented approach on the exercise of school leadership - which is multiple and complex. Nevertheless, we let ourselves go with the challenge of analyzing singular perceptions on aspects such as the educational success of students, professional development of teachers and organizational development of the school. We also tried to identity features and personal characteristics of the school principals that eventually contribute to a successful leadership.

To this end, we conducted five case studies with principals who exercise their activity in schools in different Portuguese contexts, aiming to find out convergence or divergence in successful leaders. We must remember that the selection criteria of the participants in this study sat in the process of external evaluation of schools - these principals were all classified as "Very Good", the maximum rating in this domain.

Analyzing similarities and differences in successful leadership was the general goal guiding this study which includes five case studies involving the principals in distinct geographical settings — urban, suburban and rural — from a single region of Portugal, the Algarve.

We focused our research on the following aspects for analysis: the pupils' academic success, the teachers' professional development, the development of the schools, and the identifying features of the school principals.

In these findings, which we have described as "preliminary" once they are the result of an initial approach into successful leaderships when comparing the geographical areas, there are no differences worthy of note, with all the principals interviewed focusing on the establishment of partnerships with a variety of organizations (local councils, health authorities, associations and others), involvement 
in projects and, in a fairly significant way, the commitment of parents to the pupils' academic success. It is in this context that authors such as Ross and Gray (2006) and Robertson (1998) stress the importance of leadership in promoting commitments and partnerships and appeal for the involvement of all the educational players as partners in a global project to promote school and academic success. This comprehensive vision that academic success does not relate merely to the school, but that it is also built with the help of "others", seems clear in the results obtained.

As regards leadership practices that contribute to the inclusion of "all" pupils and in order for success to be achieved in a variety of academic and educational performance indicators, we highlight the importance given to promoting equal opportunities regardless of the social and/or cultural origin of the pupils. As a differentiating aspect, we found that it was in the urban and rural settings that the greatest value was given to the school and learning and to their socializing and equalizing effects. It is in these geographical areas that the constant search for personalized pedagogical responses, centered on pupils' characteristics, takes on particular significance.

In the interview conducted with the principal of the rural school, the school's importance in expanding the individual horizons of the pupils was also mentioned, which seems to be expectable considering that, in cases like this, the scarcity of offerings and stimuli confer an enormous educational responsibility upon the school. Costa (2000) and Bolívar (2012) also emphasize the importance of school leaderships as a means for developing educational and pedagogical action and see the principal as a key factor for change and improvement in schools, even being determining for the improvement of education. The data confirm this assumption, above all when the "school" takes the stance — and does so consciously — of the institution in the community with the most substantial share in the educational and cultural development of the inhabitants.

It was also our intention to discover leadership actions that reflect on the teachers' professional development and, consequently, on the quality of their teaching practices. In the Portuguese educational system, the management and leadership model has been characterized by internal decentralization, which is exercised in a disperse way and gives rise to multiple leaderships that operate in an articulated and complementary manner.

These leadership practices are based on rotational roles, due to the possibility that teachers have to undertake different functions/roles within the school. According to some authors (Beattie, 2002; Gold et al., 2003; Leithwood, 1994), this fact expands the perception that educational players have of the reality, enables learning from and with others, and promotes a culture of collaboration. In this study, we identified all settings studied shared aspects on the fostering of motivation and endeavor among teachers, the strengthening of commitment to the teaching profession's "mission" and, additionally, the creation of a good working atmosphere conducive to the teachers' cooperation and identification with their schools.

The differences were mainly in the suburban setting, where the incentive for teachers to undergo continuous training, support in dealing with the difficulties and problems felt and/or encountered and the support for projects presented by 
the teachers stand out. In the rural setting, the need to make lessons more stimulating and to valorize the "nobility" of teaching was acknowledged. It is in this context that reference is made to the advantages of rotating teaching staff as a factor that encourages professional development that constitutes a scenario whereby communities with practical knowledge can be created (Bolívar, 2012). When they share professional competences and skills, it becomes a means for professional and organizational development.

Some differences between the three geographical areas have been found, which are related to specific characteristics such as the facility to access to training programs, given the school's isolation. Nevertheless, all the principals interviewed demonstrated awareness that leadership has an enormous impact on teachers' professional development (Bolívar, 2012; Leithwood, 1994).

As far as the organizational development of the school is concerned, we noted, as a common denominator among the three geographical areas, that leadership style and practices were recognized as influencing the school's development, as was the participation in initiatives by other organizations, displaying the school's internal strategy. The interviewees also emphasized the promotion and undertaking of self-assessment by the school.

The decision-making processes based on the awareness that the dissemination of information, both externally (school/community) and internally (between the various educational units and the different protagonists in the teaching and learning process), is fundamental, both for the fulfilment of the school's mission - the pupils' academic and educational success - and for the development of the institution as an organization. As Fullan (2001) says, this dissemination of information is not insignificant, highlighting that it is actually fundamental for the acquisition of knowledge about the various dimensions of the school's organizational functioning, stimulating change. The school principals, by implementing decisions that imply making what is done in the school known internally and externally, promote communication processes in which the teaching practices extend their effectiveness.

Comparing the three geographical areas, the schools belonging to suburban settings appear to invest more in consulting the community, in drawing up documents that structure life in the school, taking an approach of constant dialogue. These leaderships also promote reflection among the teaching staff so that they can identify "how" and "where" the school can improve. While the data gathered also indicate problems in accommodating the teaching staff and other difficulties, the prevalent leadership approach in the suburban setting is an effort to attenuate the problems, calling upon the educational players to make a more effective commitment to school life. In this type of setting, the stimulus towards a feeling of "belonging" shared by everyone involved in the school - teachers, pupils and non-teaching staff — is more visible. From this, one might infer that some of the typical limitations of these settings, and which were mentioned by the interviewees, such as the small number of inhabitants, communication difficulties and even reduced expectations on the part of the educational community, could actually turn into advantages, appealing, as Sergiovanni says $(1998,2004)$, to the use of strategies 
for shared leadership practices and for the individual and collective endeavor of the entire educational community (English, 2008; Fullan, 2001; Nóvoa, 1992).

As for the development of the organizational structure, what differentiates the three settings is the deffence of the school autonomy as an instrument for the school's affirmation. According to principals from both suburban and rural schools, only autonomy enables the school to be seen as an example of local power in the community, to which it belongs, providing a separate identity on each school.

Moving on now to the identifying features, and although the principals have very distinct characteristics, there are common traits that can be identified. All of the interviewees consider to be playing a fundamental role; not only because of institutional authority but also because of the "personal stamp" they confer upon their own performance and which is the result of their own particular personality traits.

According to Sanches (1996) and English (2008), the exercise of leadership entails a vast array of competences acquired through training and practical experience. In the case of the principals interviewed, they did not undergo specific academic training in "school leadership". Thus, the way in which they do their jobs depends largely on a career path involving learning "for" and "on" the job, with a series of personal characteristics undoubtedly being a contributory factor to the quality of their performance. All of them obtained a classification of "Very Good" in the schools' external evaluation process. Thus, in these cases, rather than simply emphasizing the importance of training, it is important to mention personal characteristics of these principals which, according to various authors (Ciscar \& Uria, 1986 apud Gairín-Sallán \& Villa Sánchez, 1999), are variable but undeniably contribute to the quality of their leadership. The shared personality traits are affection and the capacity to relate to others, both internally and with the community, and which facilitate the motivation and mobilization of the different educational agents and partners. Apart from these personal characteristics, all consider that the exercise of leadership requires a comprehensive long-term vision of the School as an organization, which translates into a clear and consensual definition of goals, for whose attainment the entire educational community should feel a sense of involvement.

We can conclude, therefore, that although our principals took different career paths and do their jobs in distinct settings which require equally differentiated interventions, it was possible to detect a series of identifying features common to all. In other words, we can therefore affirm that there is no leadership profile; rather, there are "performances" which are variable. The "person" of the principal is an instrument in variability, as well as in the context in which they do their job. This conclusion is congruent with the opinion of various authors who see opportunities to be innovative and creative in the exercise of leadership, believing that school principals are agents of change insofar as they are able to put their own skills and those of the people they work with to good use "in benefit of a shared vision and mission" (Bolívar, 2012, p. 67). 


\section{ACKNOWLEDGEMENTS}

The authors would like to thank to Manuel Mariano, Alexandra Ferreira, Maria Fernanda Ferreira, Cláudio Galego, Tânia Teixeira and Sónia Favinha for their contribution to this paper.

\section{REFERENCES}

Almeida, L.; Freire, T. Metodologia da Investigação em Psicologia e Educação. 5. a ed. Braga: Psiquilíbrios, 2008.

Alves, J. M. Autonomia, participação e liderança. In: Carvalho, A.; Alves, J. M.; Sarmento, M. J. Contratos de Autonomia: aprendizagem organizacional e liderança. Porto: ASA, 1999. p. 15-33.

Ainley, J.; McKenzie, P. School Governance: Research on Educational and Management Issues. International Educational Journal, v. 1, n. 3, p. 139-151, 2000.

BAR KER, B. The Leadership Paradox: Can school leaders transform student outcomes? School Effectiveness and School Improvement, v. 18, n. 1, p. 21-43, 2007.

BeAtTie, M. Educational Leadership: modeling, mentoring, making and re-making a learning community. European Journal of Teacher Education, v. 25, n. 2/3, p. 199-221, 2002.

BogdAn, R.; BıKLEN, S. Investigação qualitativa em educação: uma introdução à teoria e aos métodos. Porto: Porto, 1997.

Bolívar, A. Liderazgo, Mejora y Centros Educativos. In: Medina, A. (Coord.). El liderazgo en educación. Madrid: UNED, 1997. p. 25-46.

. Melhorar os Processos e os Resultados Educativos: o que nos ensina a investigação.

Vila Nova de Gaia: Fundação Manuel Leão, 2012.

Carvalho, J. E. Metodologia do trabalho científico. Lisboa: Escolar, 2002.

Cohen, L.; Manion, L. Métodos de Investigación Educativa. Madrid: La Muralla, 1990.

Coppieters, P. Turning schools into learning organizations. European Journal of Teacher Education, v. 28, n. 2, p. 129-139, 2005.

Costa, J. A. Liderança nas Organizações: revisitando teorias organizacionais num olhar cruzado sobre as escolas. In: Costa, J. A.; Mendes Neto, A.; Ventura, A. (Orgs.). Liderança e estratégia nas organizaçôes escolares. Aveiro: Universidade de Aveiro, 2000. p. 15-33.

Creemers, B.; Reezigt, G. Linking School Effectiveness and School Improvement: The background and outline of the project. School Effectiveness and School Improvement, v. 16, n. 4, p. 359-371, 2005.

Decree-Law 75/2008, of 22 April - Legal Framework for Autonomy, Administration and Management of public Pre-school, Basic and Secondary Education Schools. 2008. Decree-Law 224/2009, of 11 September - First amendment to the Legal Framework for Autonomy, Administration and Management of public Pre-school, Basic and Secondary Education Schools. 2009. 
Decree-Law 137/2012, of 2 July - Second amendment to the Legal Framework for Autonomy, Administration and Management of public Pre-school, Basic and Secondary Education Schools. 2012.

English, F. The Art of Educational Leadership: Balancing Performance and Accountability. London: Sage, 2008.

Estêvẽo, C. V. Liderança e Democracia: o Público e o Privado. In: Costa, J. A.; Mendes Neto, A.; Ventura, A (Orgs.). Liderança e estratégia nas organizaçóes escolares. Aveiro: Universidade de Aveiro, 2000. p. 35-44.

Fuick, U. Métodos Qualitativos na Investigação Científica. Lisboa: Monitor, 2005.

Fonseca, A. A liderança escolar e a comunicação relacional. In: Costa, J. A.; Mendes Neto, A.; Ventura, A. (Orgs.). Liderança e estratégia nas organizações escolares. Aveiro: Universidade de Aveiro, 2000. p. 137-151.

FoRTin,M.-F. O processo de investigação: da concepção à realização. Loures: Lusociência, 2000. Fullan, M. Leading in a Culture of Change. San Francisco: Jossey-Bass, 2001.

Gairín-Sallán, J.; Villa Sánchez, A. Los Equipos Directivos de los Centros Docentes: Análisis de su funcionamiento. Bilbao: Universidad de Duesto, 1999.

Glatter, R. As escolas e os sistemas de ensino perante a complexidade: desafios organizacionais. In: Inspeção Geral de Educação (Org.). Actas da Conferência "As escolas Face aos Novos Desafios". Lisboa: IGE, 2007.

Gold, A. et al. Principled principals? Values-Driven Leadership: Evidence from ten case studies of "outstanding" schools leaders. Educational Management $\Xi$ Administration, v. 31, n. 2, p. 127-137, 2003.

Guerra, I. Pesquisa Qualitativa e Análise de Conteúdo: sentidos e formas de uso. Estoril: Princípia, 2006.

Leithwood, K. Leadership for school restructuring. Educational Administration Quarterly, n. 30, p. 495-518, 1994.

NóvoA, A. Para uma análise das instituições escolares. In: (Coord.).As Instituiçôes Escolares em Análise. Lisboa: Dom Quixote, 1992. p. 13-43.

Quivy, R.; Campenhoudt, L. V. Manual de Investigação em Ciências Sociais. 2. a ed. Lisboa: Gradiva, 1995.

Regulatory Ordinance 13-A/2012, of 5 June - Establishes the mechanisms for the exercising of pedagogical and organisational autonomy of every school, and harmonises them with the principles laid down in the Legal Framework for Autonomy,Administration and Management of public Pre-school, Basic and Secondary Education Schools. It grants schools greater flexibility in the organisation of academic activities and aims to increase efficiency in the distribution of the service and valorise academic results. 2012.

Robertson, J. From managing impression to leadership perspectives. International Journal of Educational Research, v. 29, p. 359-370, 1998.

Ross, J.; Gray, P. Transformational Leadership and Teacher Commitment to Organizational Values: The mediating effects of collective teacher efficacy. School Effectiveness and School Improvement, v. 17, n. 2, p. 179-199, 2006. 
Ruzafa, J. A. M. La dirección de centros escolares. In: González, M. T. (Coord.). Organización y Gestión de Centros Escolares. Dimensiones y Procesos. Madrid: Pearson Educación, 2003. p. 225-241.

SANChEs, M.F.C. Imagens de liderança educacional: acção tecnocrática ou acção moral e de transformação? Revista de Educação, v. VI, n. 1, p. 13-35, 1996.

Sergiovanni, T. Leadership as a pedagogy, capital development and school effectiveness. International Journal of Leadership in Education, v. 1, n. 1, p. 37-46, 1998.

. Novos caminhos para a liderança escolar. Porto: ASA, 2004.

\section{ABOUT THE AUTHORS}

Helena Luísa Martins Quintas has a doctorate in educational sciences from the Universidade do Algarve (Portugal). She is a professor at the same institution. E-mail: hquintas@ualg.pt

José Alberto Mendonça Gonçalves has a doctorate in educational sciences from the Universidade de Lisboa (Portugal). He is a professor at the Universidade do Algarve (Portugal).

E-mail: jamgoncalves@sapo.pt

Sandra Cristina Andrade Teodósio dos Santos Valadas has a doctorate in educational sciences from the Universidade do Algarve (Portugal). She is a professor at the same institution.

E-mail:svaladas@ualg.pt 